\title{
Sedimentary Environments and Coal Accumulation of the Middle Xishanyao Formation, Jurassic, in the Western Dananhu Coalfield, Turpan-Hami Basin
}

\author{
Zhiming Yan, ${ }^{1}$ Jinlong Wang, ${ }^{1}$ and Xuetian Wang $\mathbb{D}^{2}$ \\ ${ }^{1}$ Institute of Architectural Engineering, Weifang University, Weifang 261061, China \\ ${ }^{2}$ College of Geoscience and Surveying Engineering, China University of Mining and Technology (Beijing), Beijing 100083, China
}

Correspondence should be addressed to Xuetian Wang; 827828904@qq.com

Received 30 June 2021; Revised 15 September 2021; Accepted 25 September 2021; Published 2 November 2021

Academic Editor: Xudong Zhang

Copyright ( 2021 Zhiming Yan et al. This is an open access article distributed under the Creative Commons Attribution License, which permits unrestricted use, distribution, and reproduction in any medium, provided the original work is properly cited.

\begin{abstract}
The Dananhu coalfield, at the southern margin of Turpan-Hami Basin, Xinjiang, has good coal-forming geological conditions. Due to the low research level on the depositional environment and coal accumulation, the comprehensive coal mining is restricted. Based on drilling and sectioning outcrop data, the depositional characteristics, lithofacies, paleogeography, and coal accumulation of the coal-bearing formations in western Dananhu coalfield are analyzed. The middle member of the Xishanyao Formation is the major coal-bearing strata of the Dananhu coalfield, composed of conglomerate, sandstone, siltstone, mudstone, and combustible organic rock, which can be further subdivided into 14 lithofacies according to substance composition, sediment texture, and structure. During the early Middle Jurassic coal-accumulating period, alluvial fan, fluvial plain, fluvial delta, and shallow lacustrine deposits were developed from northeast to southwest in the western Dananhu mining area. Coal accumulation was most developed in the center regions of the study area extending from northeast to southwest, which were primarily concentrated in margin fans, floodplains, interdeltaic bays, and lakeshore environments, especially the transitional zone between the fluvial plain and the delta plain in the west of No. 1 mining area. This coal accumulation was mainly controlled by synsedimentary tectonic subsidence and clastic sediments supply or sedimentary environment, where tectonic subsidence was the primary controlling factor and the source supply was the secondary controlling factor for coal accumulation, which provided theoretical support for the coal prediction and geological exploration in western Dananhu coalfield.
\end{abstract}

\section{Introduction}

In recent years, with the discovery of thick coal seams formed in Jurassic continental basins in northwestern China, special attention has been paid to the application of sequence stratigraphy and sedimentary characteristics and coal accumulation to continental coal measures [1-8]. The Turpan-Hami Basin, rich in oil, gas, and coal resources, is an important energy basin for energy exploration and development in northwestern China [1,9]. The Xishanyao Formation of Middle Jurassic in Turpan-Hami Basin is the main coal bearing series containing abundant paleoclimate evolution information during the coal accumulation period
$[10,11]$, already being a focus for the sedimentary evolution and energy geology research [12-16]. The Dananhu coalfield in the Turpan-Hami Basin is the 14th largest coal base in China. Since its abundant and stable coal seams, it has already been widely concerned by internal and external scholars. Recently, many researches, such as coal seam comparison [17-19], coalbed methane geology [20, 21], and geophysical exploration [22, 23], have been obtained; however, most of them are concentrated in the key development regions of the Dananhu mining area and few are on the northwest, especially the western region. In consequence, geological exploration and production development of coal resources in the western region have been greatly limited 


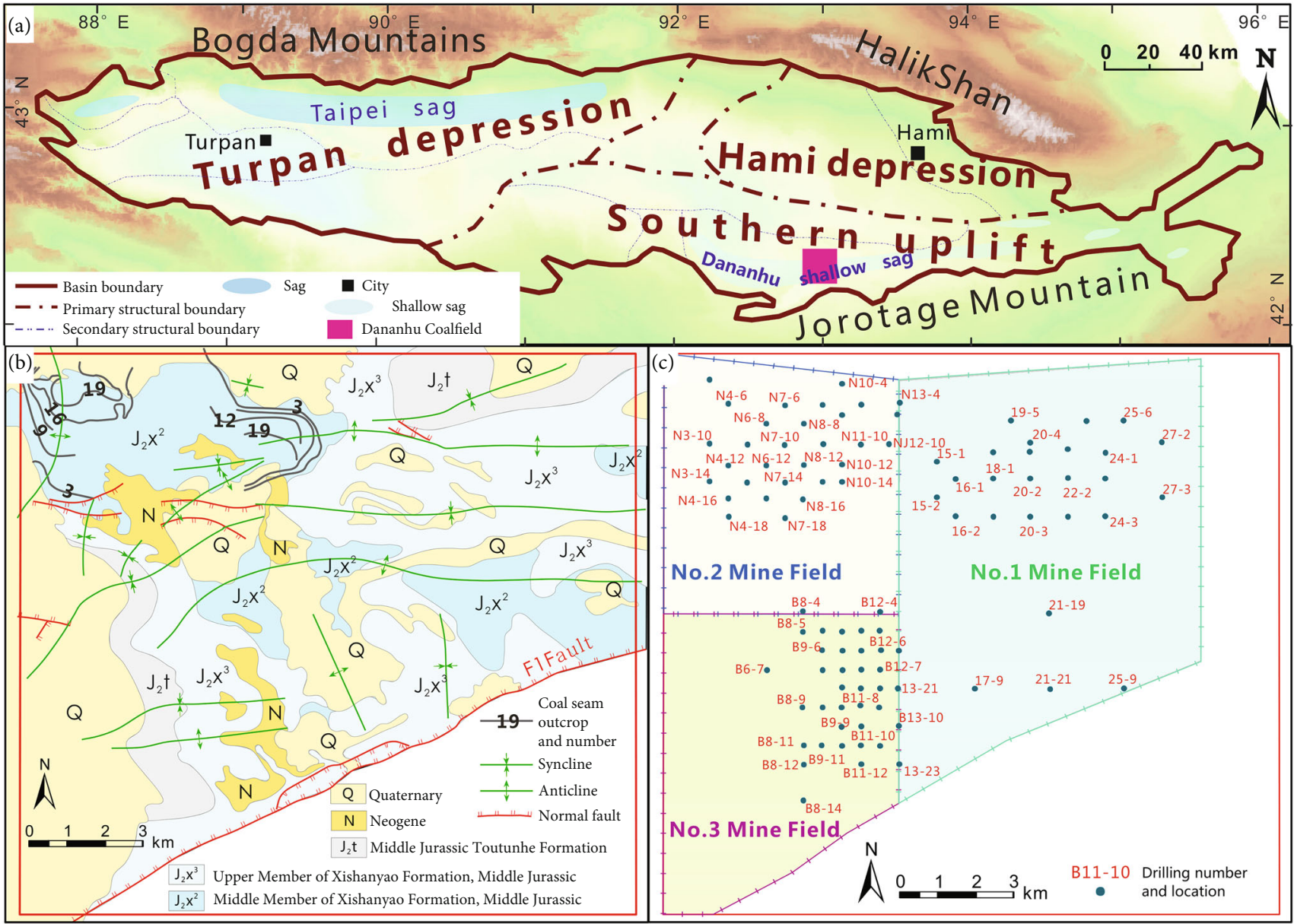

FIGURE 1: Geological background of western Dananhu coalfield: (a) regional tectonic setting; (b) geological map of study area; (c) location of drillings.

for the rare reports on depositional environment and coal accumulations, and also, far less is known about the genetic mechanism of the huge thick coal seams in this area.

In this paper, based on the drillings and logging data from the No. 1, 2, and 3 mining areas in the west of the Dananhu coalfield (Figure 1(c)), the sedimentological characteristics of the terrestrial coal measures from the middle member of the Xishanyao Formation are presented and sedimentary environment and the paleogeography during the coal accumulation period are reestablished. From these data, a coal accumulation model as well as the factors controlling the coal seams development is proposed. It is anticipated that this work will not only facilitate coal prediction and geological exploration, but it will also provide theoretical support for the development and utilization of coal resources.

\section{Geological Context}

The Dananhu coalfield, located on the southern margin of the Turpan-Hami Basin, is about $80 \mathrm{~km}$ southwest to Hami City, belonging to the Dananhu shallow sag. It is adjacent to the Yishaer Lake uplift belt in the north and the F1 fault as well as the Jueluotag anticlinoria in the south. Controlled by the tectonic evolution of the Turpan-Hami Basin, during the late Yanshanian period, the middle and upper parts of the Jurassic in Dananhu coalfield were eroded because of the collision and compression of the Qiangtang block. During the Himalayan period, a series of faults and fold structures extending north-east were formed since the combined action of the compression of the Haerlik Mountain from southwest and the blocking of the southern marginal mountain system [24-26] (Figure 1(a)).

The regional stratum exposure in Dananhu coalfield mainly includes the Xishanyao Formation and Toutunhe Formation of the Middle Jurassic and some of the Neogene and Quaternary (Figure 1(b)). The coal-bearing strata are the Sangonghe Formation of Lower Jurassic, Xishanyao Formation, and Toutunhe Formation of Middle Jurassic ascendingly. The main coal-bearing stratum is the middle member of Xishanyao Formation, dominated by fine clastic rock and rich in plant fossils with a total thickness of $350 \sim 650 \mathrm{~m}$ and an average of $477 \mathrm{~m}$. This member contains 52 coal seams in total, and the total thickness is in the range of $36-142 \mathrm{~m}$, in average of $92.3 \mathrm{~m}$, among which 24 seams are mineable $[17,19]$.

The Dananhu shallow sag began to sink significantly during the late Early Jurassic period (mid-Sangonghe) and 
formed the steep slope resulting in a large amount of debris flows accumulated from the northern provenance area and then filled the southern lakes. Lake transgression developed extensively in the basin which was not suitable for the wide spread of peat mires. In the early Xishanyao period, the subsidence in the basin was still strong. Since the filling and replenishing effect, terrain tended to be gentle, and the lake water became shallower, resulting in increased lake transgression range and regressed fan deltas areas around the lake. Coal seams only developed in parts of the fan delta plains. In the middle Xishanyao period, as the coastline migrated southward, the alluvial fan-fan delta-lake systems evolved into the alluvial fan-fluvial plain-delta-lake systems. Then, the tectonic subsidence remained stable for a long time. Because the Dananhu shallow sag and Turpan-Hami Basin were relatively isolated and lake level seldom changed, peat mires in sag sustained to develop stably under the suitable climates, forming a large area of extrathick coal seams. In the late Xishanyao period, lake basins continued to sink, and the continuous and slow lake transgression caused the coal accumulation to gradually cease $[10,27,28]$.

\section{Sedimentary Characteristics and Environments of the Middle Member of Xishanyao Formation}

3.1. Rock Types and Lithofacies Characteristics. Based on the field observations on lithological, paleontological, and paleobotanical criteria of the drilled cores in the study area (Figure 1(b)), five distinct rock types, such as conglomerate, sandstone, siltstone, mudstone, and combustible organic rock (coal), were identified in the middle member of the Xishanyao Formation. Combining rock composition, texture and sedimentary structure characteristics, 14 lithofacies types can be further divided: (1) matrix supported conglomerates, (2) particles supported conglomerates, (3) massive bedding sandstone, (4) ripple laminated bedding sandstone, (5) tabular cross-bedding sandstone, (6) parallel bedding sandstone, (7) trough cross-bedding sandstone, (8) pebbled coarse sandstone, (9) massive bedding siltstone, (10) horizontal bedding siltstone, (11) ripple laminated bedding siltstone, (12) mudstone, (13) carbon mudstone, and (14) coals (summarized in Table 1).

Conglomerate, with poor sorting and rounding, can be divided into matrix-supported conglomerate and particlesupported conglomerates according to the support method. The matrix-supported conglomerates, developing erosional bases with basal cementation, were most likely to form in the braided channel and debris flow deposits of alluvial fans or fan deltas. Gravels in particle-supported conglomerate are arranged in an imbricate pattern occasionally, with porouscontact cementation. These conglomerates are suggested to have mostly formed in braided channel deposits of alluvial fans and fluvial plains.

According to the sedimentary structure, sandstones can be divided into massive bedding sandstone, ripple laminated bedding sandstone, parallel-bedded sandstone, tabular cross-bedded sandstone, trough-shaped cross-bedded sand- stone, and massive pebbled coarse sandstone. The massive bedding sandstones are normal-sorted and rounded and were mostly developed in delta mouth bars and alluvial fan sheet flow deposits. Ripple laminated bedding sandstones are normal-well sorted and rounded, which were suggested to be widely distributed in sedimentary environments such as natural levees, flood plains, crevasse splays, interdeltaic bays, lakeshore, and shallow lakes. The tabular crossbedding sandstones are normal-rounded, with scour surfaces visible at the bottom, which were likely to develop in river beaches and mouth bars. Parallel bedding sandstones are well sorted and rounded, with stripping lineation which can be seen on bedding plane, reflecting the high energy of water flows, which were mostly developed in fluvial plains, interdeltaic channels, and mouth bars. Trough-shaped cross-bedded sandstones are generally rounded, with occasional bottom scour surfaces, which were most likely to develop in fluvial plains and interdeltaic channels. Massive pebbled coarse sandstones are poor-sorted and normalrounded, with base-porous cementation and abundant tree trunk fossils as well as some bottom scour surfaces. These are mostly suggested to have formed in channel lags of braided channels, river floodplains, and mouth bars of alluvial fans, fluvial plains, or fan deltas.

According to the sedimentary structure, siltstones can be divided into massive bedding siltstone, horizontal bedding siltstone, and ripple laminated bedding siltstone. Massive bedding siltstones contain plant debris fossils and were interpreted as having formed in environments of river beaches, mouth bars, and distal bars. Horizontal bedding siltstones are well-sorted and normal-rounded and contain plant leaf fossils. They were suggested to be widely developed in flood plains, interdeltaic bays, distal bars, lakeshore, and shallow lakes. Ripple laminated bedding siltstones are moderate-well rounded, which were likely to be widely developed in braided river floodplains, meandering river natural levees, interdeltaic bays, crevasse splays, distal bars, lakeshore, and shallow lakes.

Mudstones are divided into mudstone and carbonaceous mudstone according to the composition characteristics. The mudstone, with occasional pyrite found, was indicatively distributed in the sedimentary environments as flood plain, interdistributary bays, lakeshore, and shallow lakes. Carbonaceous mudstone develops horizontal bedding, with a relatively high carbon content and abundant plant debris fossils. It was probably accumulated in interdistributary bays, flood plain, and mires.

3.2. Lithofacies and Sedimentary Facies. According to the vertical sequence combination and their spatial distribution characteristics of the lithofacies types, the sedimentary environment systems of the middle member of the Xishanyao Formation in western Dananhu coalfield can be summarized as alluvial fans, rivers, deltas, and lakes (Figure 2).

Alluvial fan deposits are mostly found in near provenance area of northeastern Dananhu coalfield and are dominated by conglomerate, sandstone, siltstone, and mudstone that display an overall fining upward trend, which can be divided into root fan, midfan, and margin fan facies. 
TABLE 1: Lithofacies of the middle member of Xishanyao Formation of the western Dananhu coalfield.

\begin{tabular}{|c|c|c|}
\hline Lithology & Lithofacies & Environments \\
\hline \multirow[b]{2}{*}{ Conglomerates } & $\begin{array}{l}\text { (1) Matrix-supported conglomerates, off-white-tawny, } \\
\text { poorly sorted, subangular, basal cementation, } \\
\text { erosional bases }\end{array}$ & $\begin{array}{l}\text { Channel lags of braided channels and } \\
\text { debris flow }\end{array}$ \\
\hline & $\begin{array}{l}\text { (2) Particle-supported conglomerates, off-white, } \\
\text { poorly to moderately sorted, subrounded-subangular, } \\
\text { porous-contact cementation, occasional imbrications }\end{array}$ & Channel lags of braided channels \\
\hline \multirow{6}{*}{ Sandstone } & $\begin{array}{l}\text { (3) Massive bedding sandstone, off-white, moderately } \\
\text { sorted, subrounded-subangular, massive }\end{array}$ & Mouth bars, sheet flows \\
\hline & $\begin{array}{l}\text { (4) Sandstone with ripple laminated bedding, off-white } \\
\text { to grey-buff, moderately to well-sorted, subrounded, } \\
\text { particle-supported }\end{array}$ & $\begin{array}{l}\text { Natural levees, flood plains, crevasse } \\
\text { splays, interdistributary bays, lakeshore, } \\
\text { and shallow lakes }\end{array}$ \\
\hline & $\begin{array}{l}\text { (5) Sandstone with tabular cross-bedding, off-white, } \\
\text { moderately sorted, subrounded-subangular, } \\
\text { particle-supported, erosional bases }\end{array}$ & Point bars, mouth bars \\
\hline & $\begin{array}{l}\text { (6) Sandstone with parallel bedding, off-white } \\
\text { to grey-buff, well-sorted, subrounded, contact } \\
\text { cementation, stripping lineation can be seen on } \\
\text { bedding plane }\end{array}$ & $\begin{array}{l}\text { Point bars, distributary channels, } \\
\text { and mouth bars }\end{array}$ \\
\hline & $\begin{array}{l}\text { (7) Sandstone with trough cross-bedding, off-white } \\
\text { to grey-buff, well-sorted, subrounded-subangular, } \\
\text { particle-supported, occasionally with erosional bases }\end{array}$ & Point bars, distributary channels \\
\hline & $\begin{array}{l}\text { (8) Pebbled coarse sandstone, off-white to grey-buff, poorly } \\
\text { sorted, subangular, with basal-porous cementation, with } \\
\text { siliceous and calcareous cements, often tree trunks fossils, } \\
\text { erosional bases }\end{array}$ & $\begin{array}{l}\text { Channel lags of braided channels, } \\
\text { river beaches, mouth bars }\end{array}$ \\
\hline \multirow{3}{*}{ Siltstone } & $\begin{array}{l}\text { (9) Siltstone with ripple laminated bedding, light } \\
\text { grey, well-sorted, subrounded-subangular }\end{array}$ & $\begin{array}{c}\text { River beaches, natural levees, interdistributary } \\
\text { bays, crevasse splays, distal bars, lakeshore, } \\
\text { and shallow lakes }\end{array}$ \\
\hline & $\begin{array}{l}\text { (10) Massive bedding siltstone, dark grey, moderately } \\
\text { sorted, subrounded-subangular, occasional plant } \\
\text { debris fossils }\end{array}$ & River beaches, mouth bars, distal bars \\
\hline & $\begin{array}{l}\text { (11) Siltstone with horizontal bedding, grey, } \\
\text { well-sorted, subcircular-subangular, plant debris fossils }\end{array}$ & $\begin{array}{l}\text { Flood plains, interdistributary bays, } \\
\text { distal bars, lakeshore, and shallow lakes }\end{array}$ \\
\hline \multirow{2}{*}{ Mudstone } & $\begin{array}{l}\text { (12) Mud, dark grey coloured, interlaminations, } \\
\text { occasionally with pyrite nodule, sheet }\end{array}$ & $\begin{array}{c}\text { Flood plain, interdistributary bays, lakeshore, } \\
\text { and shallow lakes }\end{array}$ \\
\hline & $\begin{array}{l}\text { (13) Carbon mudstone, dark grey coloured, fragile and } \\
\text { easy to fade, horizontal bedding, plant debris fossils }\end{array}$ & Interdistributary bays, flood plain, mires \\
\hline $\begin{array}{l}\text { Combustible } \\
\text { organic rock }\end{array}$ & $\begin{array}{l}\text { (14) Coals, black, semibright type, banded, sheet, } \\
\text { plant debris, and stem fossils }\end{array}$ & Mires \\
\hline
\end{tabular}

Matrix-supported conglomerates are generally deposited at the bottom of the sequence, poorly sorted, and rounded, without obvious structure, which belong to the root fan facies dominated by debris flow deposition. The thinner particlesupported conglomerate and sandstone are upwardly deposited. The gravel in conglomerate is arranged in an imbricate structure. Tree trunk fossils can be occasionally found in the coarse sandstone with trough cross-bedding and parallel bedding. This belongs to middle fan facies dominated by braided channel deposits. The upper sequence consists of sandstone and mudstone spreading like a blanket on the plane, with horizontal and massive bedding. The horizontal bedding reflects the low energy of the water flow, and the massive bedding indicates the gravity flow. This belongs to the margin fan facies in the relatively flat topography dominated by sheet flow deposits. Margin fan facies can contact lakes to form braided river deltas or directly enter lakes to develop fan deltas (Figure 2(a)).

Fluvial plain deposits were mainly developed in the eastern part of the western Dananhu coalfield, including conglomerates, sandstones, siltstones, mudstones, and coals. According to the channel types, it can be divided into braided fluvial plain and meandering fluvial plain, consisting of channel lag, river beaches, floodplain lakes, overbank mires, floodplains (braided rivers), natural levee, and crevasse splay (meandering rivers), which shows an upwardfining successions vertically. Pebbled coarse sandstone, with erosional base and trunk fossils, generally developed at the 


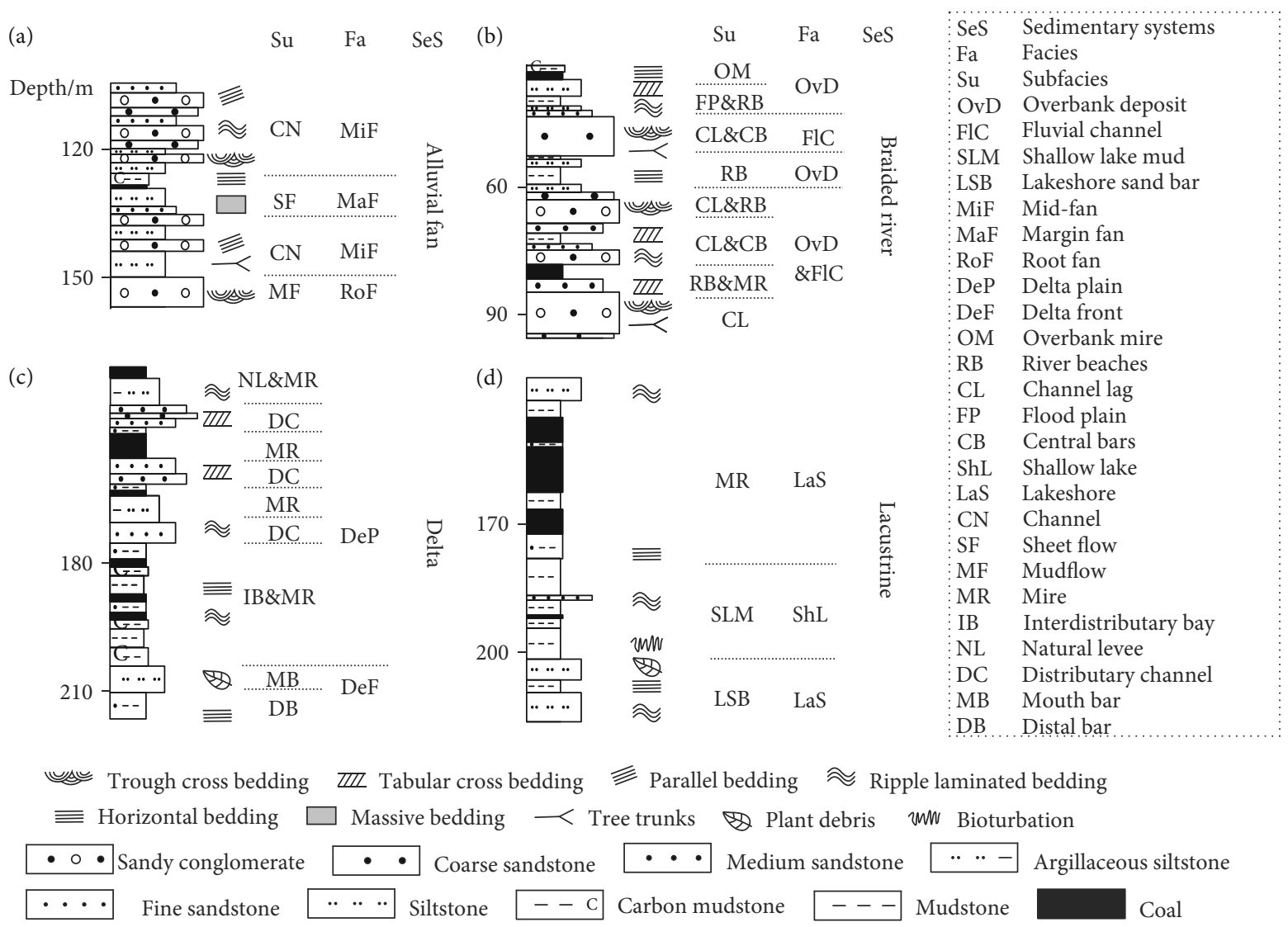

Figure 2: Typical depositional sequence of the middle member of Xishanyao Formation in the western Dananhu coalfield: (a) alluvial fan; (b) fluvial plain; (c) delta; (d) lacustrine.

bottom, where gravels were arranged in a certain direction, which were the channel lag deposits. The sedimentary sequence transitioned upward to medium-fine sandstones developing trough and tabular cross-bedding with single layer thickness of generally 2-6 m, which were channel point bar deposits. In comparison with meandering rivers, the overlapping and cutting degree of channel sands in braided rivers is higher. The upper sequence is composed of thin bedded siltstone and mudstone, with ripple laminated and horizontal bedding and occasional coal seams, which belong to swamps and lake deposits in floodplains (Figure 2(b)).

Delta system is mainly developed in central and western parts of the western Dananhu coalfield, including sandstones, siltstones, mudstones, and coals, which can be divided into delta plains, delta fronts, predeltas, and coastal shallow lake deposits. The delta plain system can be subdivided into distributary channels, interdistributary bays, natural levees, crevasse splays, and interdistributary mires. The delta front system can be subdivided into mouth bars and distal bars. Typical delta system includes an upward-coarse succession in the lower part and a sequence of fining upward in the upper. The lithology of the lower system is dominated by siltstone and fine sandstone, with ripple laminated, horizontal, and massive bedding as well as occasional plant leaf fossils. The argillaceous and silty sediments with ripple laminated and horizontal bedding are distal bar deposits of the delta front, and the sandy deposits with massive bedding and ripple laminated bedding are mouth bar sediments. The upper sequence is typified by generally upward-fining succession comprising of sandy, argillaceous, and coal deposits. Among this sequence, argillaceous deposits were often eroded by overlying sandy units with tabular and ripple laminated cross-bedding, and the grain size and structure scale of sandy sediments decrease in an upward trend. The cross-bedded sandy deposits are distributary channels in delta plain sediments, and the ripple laminated bedding sandstone and interbedded muddy deposits with horizontally bedding belong to natural levee and interdistributary bays sediments. The coal seams formed in the interdistributary bay mire are mostly sandwiched by distributary mud deposits or eroded by the distributary channel sands (Figure 2(c)).

The lacustrine deposits, mainly developed in southwestern part of the western Dananhu coalfield, consist of muds, siltstones, and coals, which can be subdivided into lakeshore and shallow lake deposits. Lakeshore deposits comprise silty, argillaceous, and interbedded coal seam deposits with horizontal and ripple laminated bedding as well as occasional siderite nodules and plant leaf fossils. The shallow lake system is dominated by argillaceous deposits, whose single thickness can exceed $12 \mathrm{~m}$, developing horizontal bedding and biological disturbance structures (Figure 2(d)). 


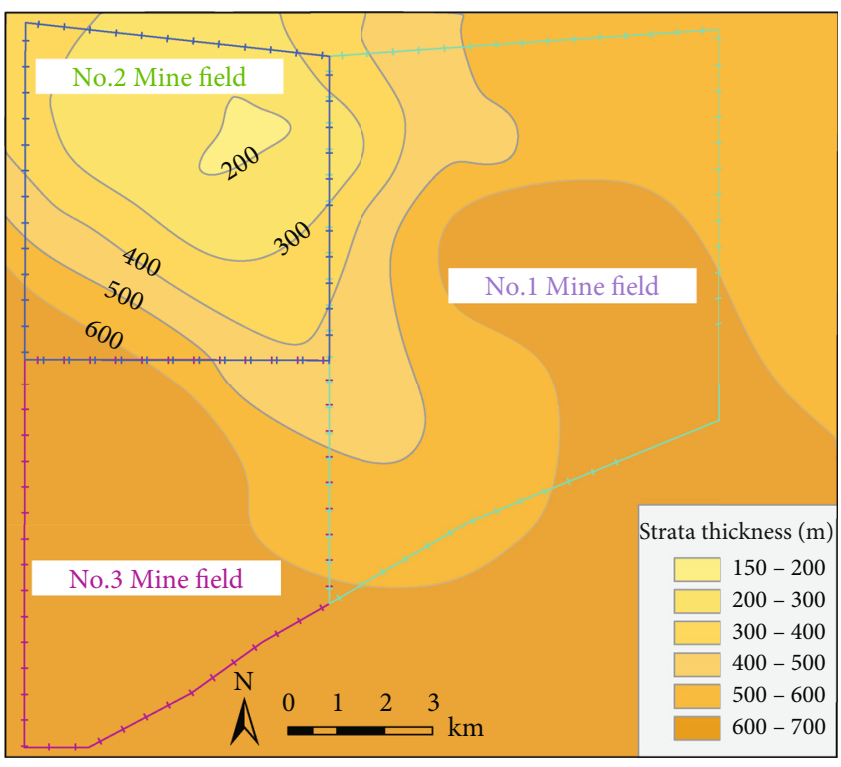

(a)

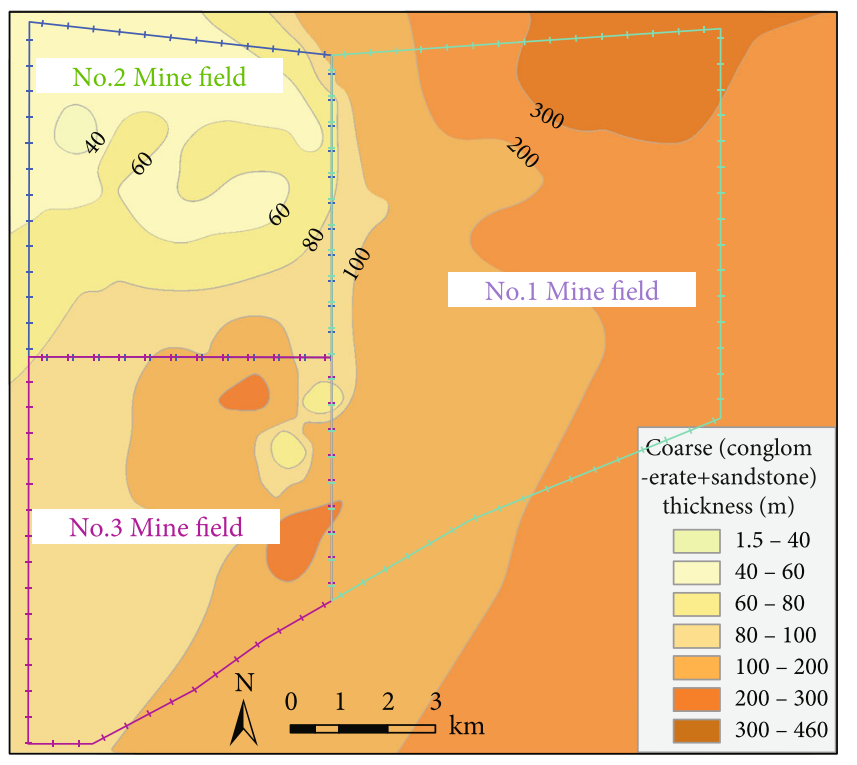

(c)

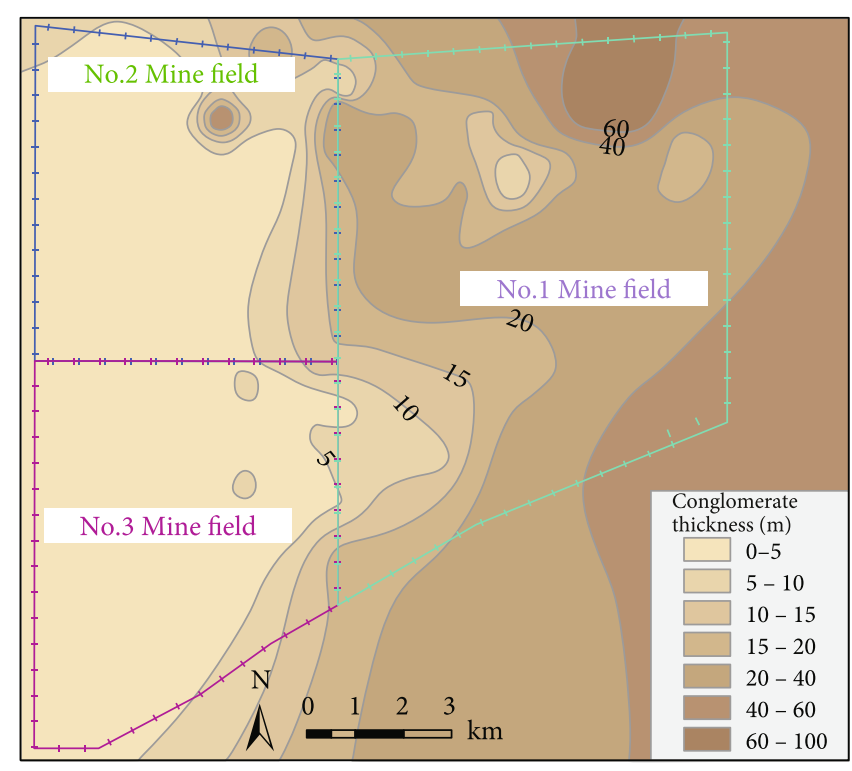

(b)

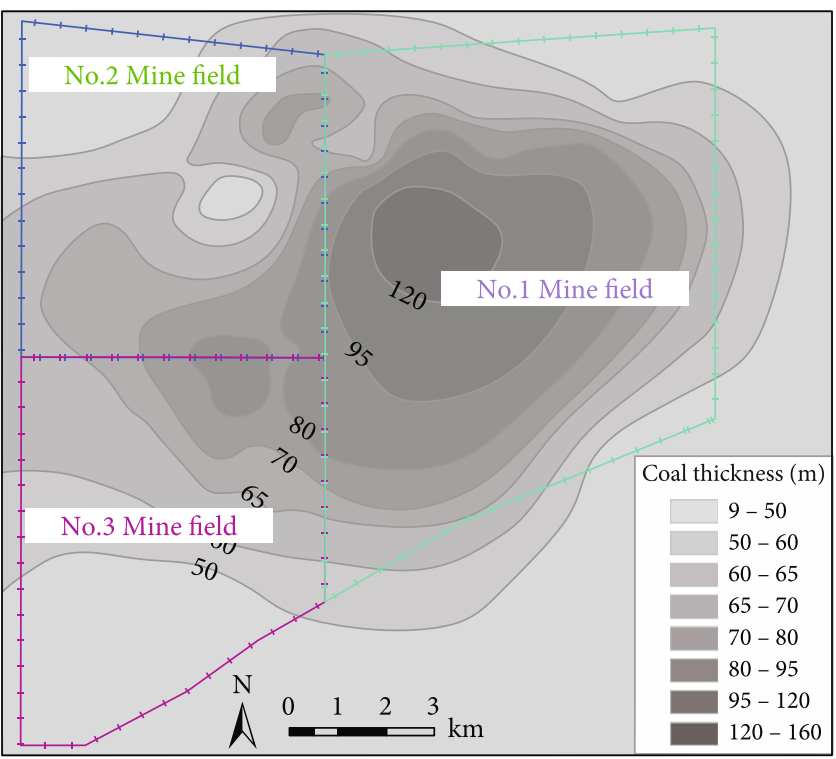

(d)

Figure 3: Continued. 


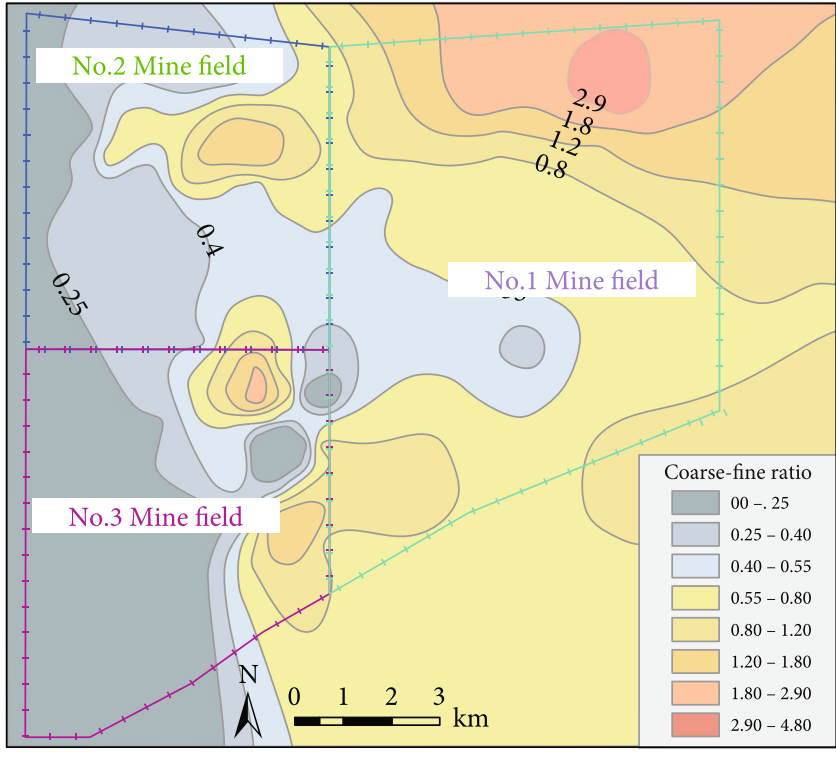

(e)

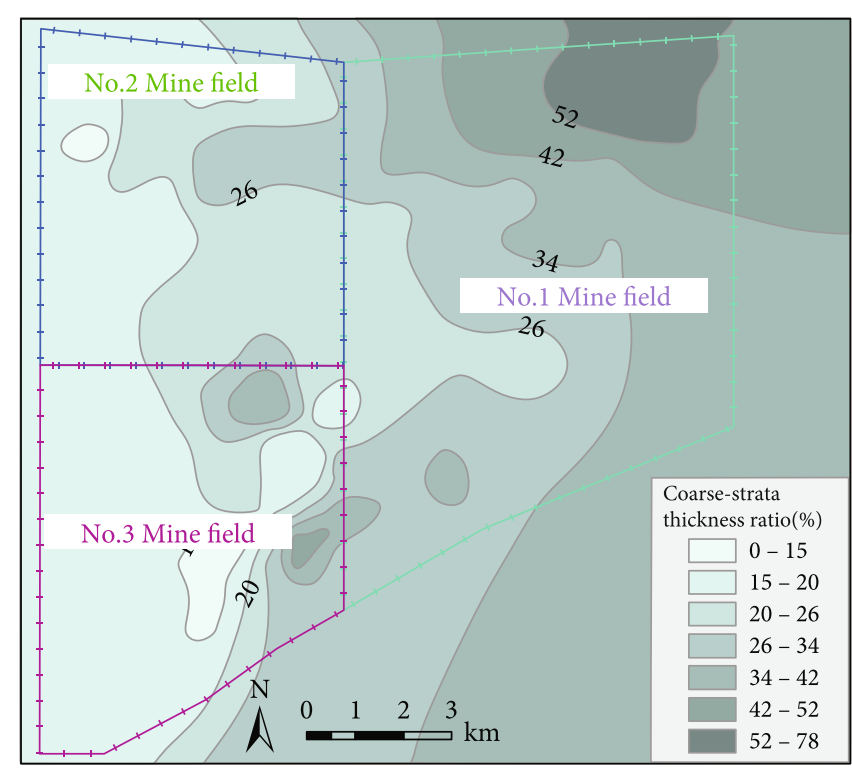

(f)

Figure 3: Contour maps of lithofacies paleogeographic factors of the middle member of Xishanyao Formation of the western Dananhu coalfield: (a) total stratum thickness; (b) conglomerate thickness; (c) thickness of coarse sediment; (d) coal thickness; (e) coarse-fine ratio; (f) coarse sediment content.

\section{Lithofacies and Paleogeography of the Middle Member of Xishanyao Formation}

The stratum thickness of the middle member of Xishanyao Formation is about $165 \mathrm{~m} \sim 772 \mathrm{~m}$. Considering the influence of open-pit mining in No. 2 mining area, the total stratum thickness is $365 \mathrm{~m} \sim 765 \mathrm{~m}$, with an average of about $550 \mathrm{~m}$. The stratum thickness gradually increases from north to south overall, with the thickest part exceeding $620 \mathrm{~m}$ located in the southwest of No. 3 mining area, followed by the southeast of No. 2 mining area generally exceeding $510 \mathrm{~m}$. The distribution of stratum thickness shows that the subsidence gradually increases from north to south and the subsidence center occurs in the southwest of No. 3 mining area; meanwhile, the subsidence in the southern part of No. 1 mining area is also relatively large (Figure 3(a)).

The thickness of the conglomerate bed ranges from 0 to $105 \mathrm{~m}$, with an average of about $10.9 \mathrm{~m}$. Since the conglomerate beds are mainly distributed in the middle and lower parts of the coal-bearing series, the bed thickness is not affected by open-pit mining and gradually increases from northeast to southwest. The thick part occurs in No. 1 mining area generally exceeding $12 \mathrm{~m}$, where the thickest appears in the northwest even reaching $65 \mathrm{~m}$ and the eastern part is also thicker with thickness of about $44 \mathrm{~m}$. Conglomerates are not developed in No. 2 and 3 mining areas which are generally less than $6 \mathrm{~m}$. The distribution of conglomerates indicates that the sedimentary supply might come from both north and east. The larger subsidence range in the south of No. 1 mining area provides sufficient accommodation space and hinders the transportation of gravel debris to the No. 3 mining area in the southwest (Figure 3(b)).

The thickness of coarse sediments (sandstones and conglomerates) is about $0-370 \mathrm{~m}$, with an average of $125.5 \mathrm{~m}$.
Despite the influence of open-pit mining areas, the thickness ranges from 75 to $320 \mathrm{~m}$. As a whole, it shows a thickened tendency from east to west, where the thickest deposits occurring in the northeast of No. 1 mining area are more than $320 \mathrm{~m}$ and the thinner part appearing in the southwest of the No. 3 mining area ranges from $75 \mathrm{~m}$ to $110 \mathrm{~m}$. The distribution of coarse sediments indicates that the detritus supply possibly came from the northeastern provenance area. The detritus mainly accumulates in the western part of the No. 3 mining area as a delta sand deposit or in the south of No. 1 mining area as a channel sand sediments (Figure 3(c)).

Coal seam thickness ranges from $25 \mathrm{~m}$ to $152 \mathrm{~m}$, with an average of $68 \mathrm{~m}$. Considering the influence of open-pit mining, the thickness changes generally from $52 \mathrm{~m}$ to $152 \mathrm{~m}$, with an average of $78 \mathrm{~m}$ and the coal content coefficient of $6-37 \%$. The maximum thickness is located from the west of No. 1 mining area to the junction between No. 1 and No. 3 mining areas, where thickness generally exceeds $83 \mathrm{~m}$ and gradually decreases to $48 \mathrm{~m}$ extending to the surrounding area (Figure 3(d)).

The coarse (conglomerate and sandstone) - fine (siltstone and mudstone) ratio ranges from 0.02 to 4.55 , with an average of 0.65 , and generally decreases from northeast to southwest. The highest ratio occurs in No. 1 mining area, ranging from 0.27 to 2.8 and decreasing from northeast to southwest, followed by No. 2 mining area with a range of $0.23-1.3$, gradually decreasing from east to west. The lowest ratio appears in No. 3 mining area generally less than 0.2 in the southwest (Figure 3(e)). The coarse sediment (conglomerate and sandstone) - strata ratio ranges from $2 \%$ to $75 \%$ and overall decreases from northeast to southwest with the maximum value located in the northeast of No. 1 mining area (Figure 3(f)). 


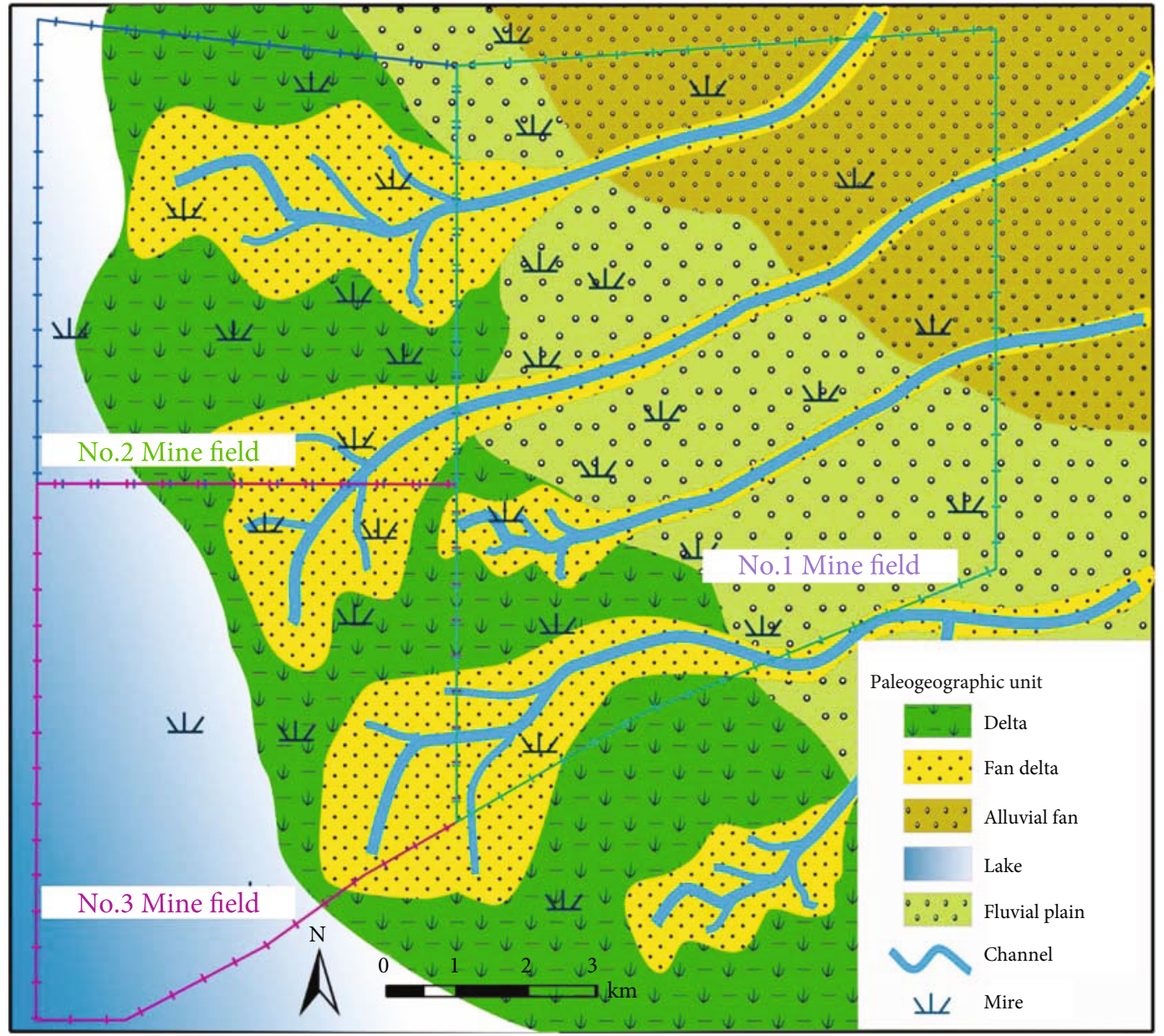

Figure 4: Lithofacies paleogeography of the middle member of Xishanyao Formation in western Dananhu coalfield.

The flat distribution characteristics of the coarse-fine ratio and coarse sediment content reflect that the sedimentary supply possibly came from the near-source alluvial fan in the northeast and the far-source alluvial system in the east of No. 1 mining area. Delta sands are distributed in the western part of No. 2 mining area, the northeastern part as well as eastern part of No. 3 mining area. Fluvial plains were widely developed between alluvial fans and delta sand sediments. Due to the lacking of sedimentary supply, the western region of No. 2 mining area and the southwestern region of No. 3 mining area formed lacustrine environments. Combining the vertical sequence (Figure 2) and the lithofacies paleogeographic single-factor contour map (Figure 3), a lithofacies paleogeography was reconstructed, among which alluvial fan and fluvial plain are bounded by a coarse-fine ratio of 1.3 and the boundary between delta and fluvial plain is the west side of the delta sand deposits (coarse-fine ratio of 0.7 ), and lakes are separated from deltas by the coarse-fine ratio of 0.35 (Figures 3 and 4).

\section{Control Factors on Coal Accumulation}

It was a warm and humid climate during the Middle Jurassic in the Dananhu coalfield area, where coal-forming plants thrived [28], and coal accumulation was widely developed in margin fans, floodplains, interdeltaic bays, and lakeshore environments mainly located in the central and western part of No. 1 mining area and eastern and southern area of No. 2 mining area as well as the junction region between No. 1 and No. 3 mining areas. On the whole, the thick coals, or coal rich areas, were primarily concentrated in the center region of the study area extending from northeast to southwest. The coal accumulation was affected by the combined effects of tectonic subsidence and material supply. The transitional zone between the fluvial plain and the delta plain with the moderate tectonic subsidence intensity in the west of No. 1 mining area was most suitable for coal accumulation.

Coal seam thickness depends on the relative balance between the growth rate of the capacity space and the rate of peat accumulation [29], and the former is comprehensively controlled by structural subsidence and sedimentary supply. Taking the balanced filling state of early Xishanyao in the Dananhu shallow sag into account, the stratum thickness can better reflect the tectonic subsidence, and the sedimentary supply can be clarified by the coarse debris contents [1]. The relationship between coal seam thickness, stratum thickness, coarse sediments content, and coarse-fine ratio (Figure 5) shows that when the stratum thickness ranges between $410 \mathrm{~m}$ and $520 \mathrm{~m}$, the coal seam thickness generally exceeds $75 \mathrm{~m}$, which indicates that tectonic subsidence was 


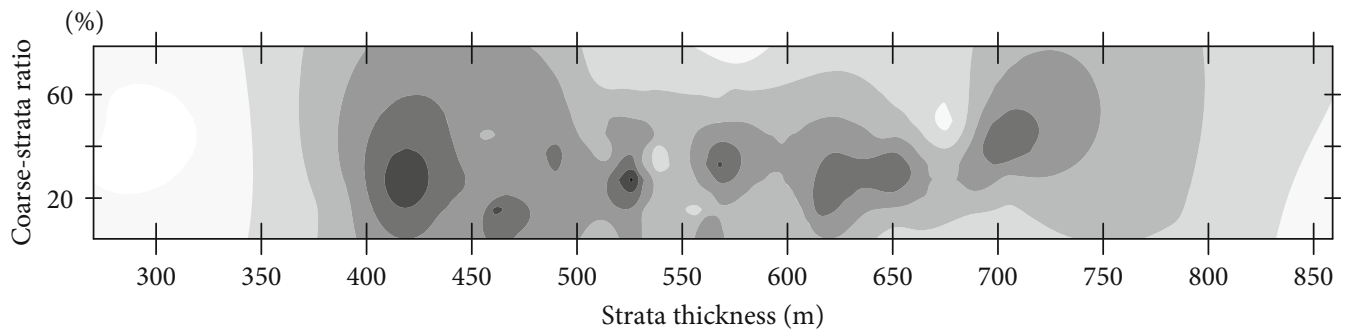

(a)

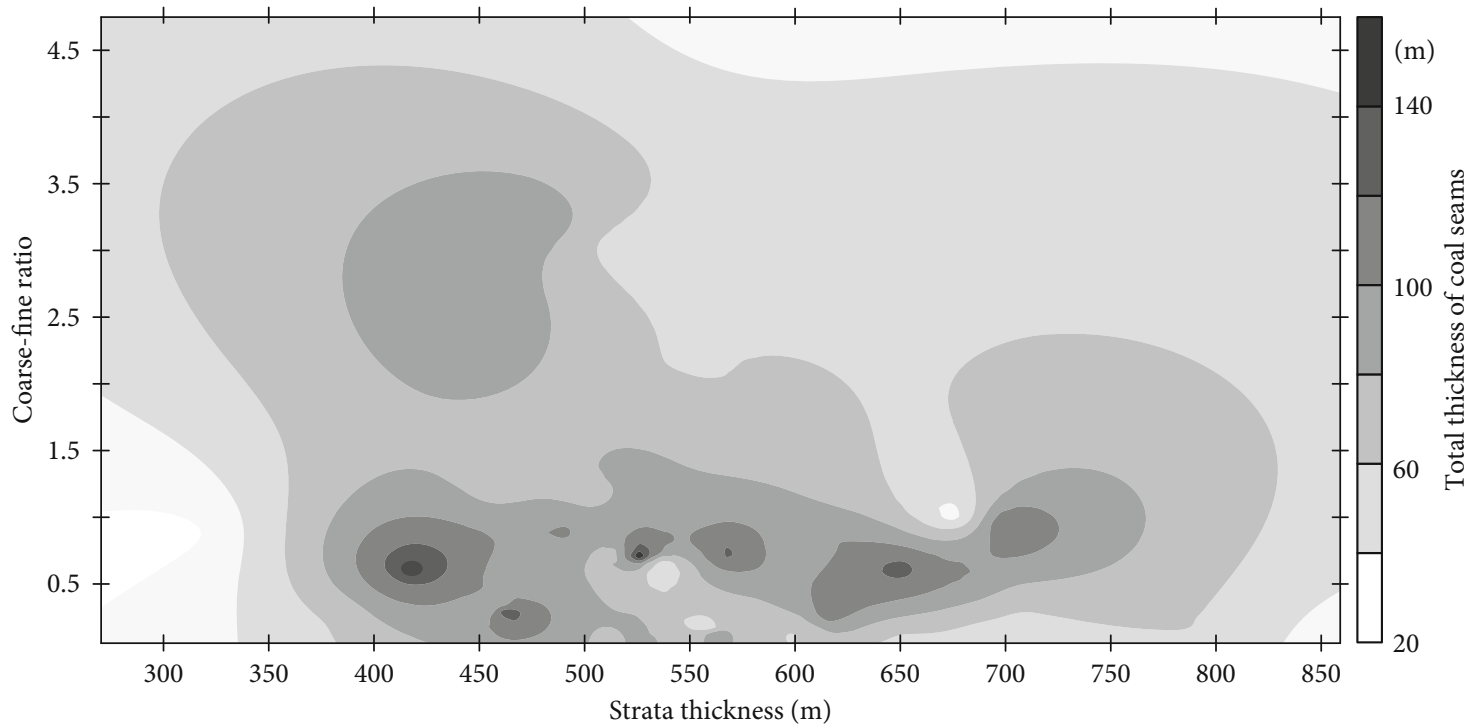

(b)

FIGURE 5: Analysis of control factors on coal accumulation: (a) relationship between coal thickness, stratum thickness, and coarse sediment (conglomerate and sandstone) - strata ratio; (b) relationship between coal thickness, stratum thickness, and coarse (conglomerate and sandstone) - fine (siltstone and mudstone) ratio.

the primary controlling factor for coal accumulation. When the stratum thickness is in the range of $400 \mathrm{~m} \sim 428 \mathrm{~m}$ and coarse sediment content is between $16 \%$ and $35 \%$, the coal seam thickness can reach $145 \mathrm{~m}$ reflecting that the most favorable combination for coal accumulation is tectonic subsidence and source supply. When the stratum thickness is more than $520 \mathrm{~m}$ and the coarse-fine ratio is in the range of $0.4 \sim 1.6$, the coal seam thickness is generally greater than $70 \mathrm{~m}$, but in some cases, it might be less than $35 \mathrm{~m}$, which state that source supply was the secondary controlling factor of coal accumulation.

\section{Conclusion}

Based on drilling and sectioning outcrop data in western Dananhu coalfield, 5 rock types: conglomerates, sandstones, siltstones, mudstones, and coals, were recognized in the middle member of Xishanyao Formation, which can be further divided into 14 lithofacies types. During the Xishanyao Formation period, depositional facies including alluvial fans, fluvial plains, deltas, and lacustrine facies were developed in the research area from northeast to southwest. Coal accumulation was most developed in margin fans, floodplains, interdeltaic bays, and lakeshore environments, which were primarily concentrated in the center region of the study area extending from northeast to southwest, especially the transitional zone between the fluvial plain and the delta plain in the west of No. 1 mining area. Coal accumulation was mainly controlled by synsedimentary tectonic subsidence and clastic sediment supply or sedimentary environment in the Dananhu shallow sag. The moderate tectonic subsidence was the primary controlling factor, and the moderate source supply was the secondary controlling factor for coal accumulation.

\section{Data Availability}

The data used to support the findings of this study are included within the article, displayed by figures and tables.

\section{Conflicts of Interest}

The authors declare no conflict of interest.

\section{Acknowledgments}

This research was supported by the National Natural Science Foundation of China (No. 42102213), which was greatly appreciated. 


\section{References}

[1] L. Y. Shao, P. Zhang, J. Hilton et al., "Paleoenvironments and paleogeography of the Lower and lower Middle Jurassic coal measures in the Turpan-Hami oil-prone coal basin, northwestern China," AAPG Bulletin, vol. 87, no. 2, pp. 335-355, 2003.

[2] B. T. Chen, X. H. Yu, T. Q. Wang et al., "Characteristics of sequence stratigraphy and coal accumulation controlling factors of Lower-Middle Jurassic coal-bearing series, south margin of Junggar Basin," Acta Sedimentologica Sinica, vol. 32, no. 1, pp. 61-67, 2014.

[3] F. J. Chen and X. W. Wang, "Prototype analysis of earlymiddle Jurassic basins in north western China," Earth Science Frontiers, vol. 7, pp. 459-469, 2000.

[4] Y. N. Fang, C. D. Wu, Y. Z. Wang, L. X. Wang, Z. J. Guo, and $\mathrm{H}$. W. Hu, "Stratigraphic and sedimentary characteristics of the Upper Jurassic-Lower Cretaceous strata in the Junggar Basin, Central Asia: tectonic and climate implications," Journal of Asian Earth Sciences, vol. 129, pp. 294-308, 2016.

[5] H. H. Hou, L. Y. Shao, Y. H. Li et al., "Influence of coal petrology on methane adsorption capacity of the Middle Jurassic coal in the Yuqia Coalfield, northern Qaidam Basin, China," Journal of Petroleum Science and Engineering, vol. 149, pp. 218-227, 2017.

[6] M. Li, L. Y. Shao, J. Lu, B. Spiro, H. J. Wen, and Y. H. Li, "Sequence stratigraphy and paleogeography of the Middle Jurassic coal measures in the Yuqia coalfield, northern Qaidam Basin, northwestern China," AAPG Bulletin, vol. 98, no. 12, pp. 2531-2550, 2014.

[7] J. J. Tian and S. G. Yang, "Sequence strata and coal accumulation of Early and Middle Jurassic in southern margin of Junggar Basin, China," Journal of China Coal Society, vol. 36, no. 1, pp. 58-64, 2011.

[8] D. W. Lv, Y. Song, L. Q. Shi, Z. L. Wang, P. Z. Cong, and A. J. van Loon, "The complex transgression and regression history of the northern margin of the Palaeogene Tarim Sea (NW China), and implications for potential hydrocarbon occurrences," Marine and Petroleum Geology, vol. 112, article 104041, 2020.

[9] Y. H. Liu, D. D. Zhao, X. W. Liu, Y. D. Wang, and J. J. Zheng, "The evolution of Turpan-Hami Jurassic Prototype Basin and its control on the distribution of source rocks," Journal of Southwest Petroleum University, vol. 34, no. 4, pp. 29-39, 2012.

[10] L. Y. Shao, D. Gao, Z. Luo, and P. F. Zhang, "Sequence stratigraphy and palaeogeography of the Lower and Middle Jurassic coal measures in Turpan-Hami Basin," Journal of Palaeogeography, vol. 11, no. 2, pp. 215-224, 2009.

[11] T. Wang, G. Q. Jing, Z. G. Liu, and B. B. Yang, "Characteristics and indicative significance of major elements in sandstone of Xishanyao Formation of Middle Jurassic in Turpan-Hami Basin," Xinjiang Geology, vol. 38, no. 2, pp. 237-242, 2020.

[12] G. Song, Simulation research on biogenic and thermogenic gas from brown coal in Dananhu Depression of Tuha Basin, China University of Mining and Technology, 2015.

[13] K. Q. Jiang, J. J. Tian, L. J. Wang, X. F. Pen, and W. Wang, "Sedimentary characteristics and coal accumulation pattern of the Xishanyao formation in southern margin area of Junggar Basin,” Geoscience, vol. 24, no. 6, pp. 1204-1212, 2010.

[14] Y. K. Li and G. Li, "Analysis on quality, petrography and facies of coal seam in Shaerhu Coalfield of Turpan-Hami Basin," Coal Science and Technology, vol. 47, no. 5, pp. 198-205, 2019.
[15] H. G. Nie, F. H. Zhao, and Y. H. Li, "Analysis on coal facies characteristics of Jurassic coal in Turpan-Hami Basin, Xinjian,” Xinjiang Geology, vol. 34, no. 1, pp. 144-149, 2016.

[16] H. Zhang, H. W. Kuang, Y. Q. Liu, and N. Peng, "The sedimentary differences of the Middle Jurassic Xishanyao Formation between Santanghu area and Turpan-Hami area and their constraint on the uplifting the Bogda Mountain," Geological Bulletin of China, vol. 32, pp. 443-455, 2013.

[17] F. S. Kong, J. K. Zhang, X. G. Duan, and G. Q. Zhang, "Coal seam correlation and study in Dananhu coalfield, Hami, Xinjiang," West-China Exploration Engineering, no. S1, pp. 116$117,2005$.

[18] C. L. Cui, "Coal seam comparative characteristics of F1 south coal mine field in Dananhu 2nd region," Science Technology and Engineering, vol. 19, no. 22, pp. 103-109, 2019.

[19] B. C. Wang, "Coalbed properties in the coal-bearing strata at Dananhu coalfield, Hami," Xinjian Geology, vol. 24, no. 2, pp. 153-156, 2006.

[20] H. H. Hou, L. Y. Shao, Y. Tang, X. L. Luo, X. T. Wang, and S. Liu, "Criteria for selected areas evaluation of low rank CBM based on multi-layered fuzzy mathematics: a case study of Turpan-Hami Basin," Geology in China, vol. 41, no. 3, pp. 1002-1009, 2014.

[21] X. S. Zhao, J. J. Tian, and S. G. Yang, "Gas distributed rule and control factors of Shaerhu Coalfield in Tuha Basin, Xinjiang," Xinjiang Geology, vol. 30, no. 2, pp. 226-228, 2012.

[22] K. H. Liang, "Application of geophysical logging of Shajihai No. 1 mine field in Xinjiang," China Energy and Environmental Protection, vol. 41, no. 10, pp. 79-84, 2019.

[23] K. H. Liang, "Application of geophysical logging in the north open-pit coal mine of Dananhu Coalfield," China Energy and Environmental Protection, vol. 42, no. 12, pp. 95-98, 2020.

[24] Y. Q. Liu, M. S. Yuan, D. W. Zhou, Q. Feng, and J. Jian, “Progress in geothermal history research in Turpan-Hami Basin, Xinjiang," Science in China (Series D), vol. 31, no. 3, pp. 257264, 2001.

[25] D. Y. Cao, L. Y. Shao, and P. F. Zhang, "Palaeotectonics in the Early and Middle Jurassic coal-forming periods of the TurpanHami Basin," Journal of Palaeogeograthy, vol. 1, no. 2, pp. 4652, 1999.

[26] J. Wang, X. J. Zhao, and Y. J. Wang, "Study on coalaccumulating structure of Turpan-Hami Basin," Xinjiang Geology, vol. 32, no. 2, pp. 266-270, 2014.

[27] Y. F. Wang, "Sedimentary environment and coalaccumulating patterns in Dananhu coalfield preliminary exploration area, Hami, Xinjiang," Coal Geology of China, vol. 16, no. 4, pp. 32-36, 2004.

[28] D. S. Zhang, G. B. Fu, E. P. Qin, Q. Z. Hou, and X. L. Li, "Jurassic palaeoclimate, palaeovegetation and palaeoenvironment in the Turpan-Hami Basin, Xinjiang," Geoscience, vol. 16, no. 2, pp. 147-152, 2002.

[29] K. Bohacs and J. Suter, "Sequence stratigraphic distribution of coaly rocks: fundamental controls and paralic examples," AAPG Bulletin, vol. 81, pp. 1612-1639, 1997. 